\title{
ENTRE VIOLÊNCIA MÍTICA E VIOLÊNCIA DIVINA: A DEPOSIÇÃO DA INSTITUCIONALIDADE JURÍDICA EM WALTER BENJAMIN
}

\author{
BETWEEN MYTHICAL VIOLENCE AND DIVINE VIOLENCE: THE DEPOSITION OF LEGAL \\ INSTITUTIONALITY IN WALTER BENJAMIN
}

\author{
Moisés João Rech* \\ João Ignácio Pires Lucas**
}

\begin{abstract}
RESUMO
O objetivo do artigo é restabelecer a crítica da institucionalidade jurídica a partir das categorias do ensaio de Walter Benjamin "Para uma crítica da violência", de 1921; mais especificamente, restabelecer a crítica do direito por meio da tensão entre as categorias violência mítica instauradora e conservadora do direito - e violência divina - depositora da institucionalidade jurídica. A hipótese subjacente acena para um rompimento com a continuidade histórica e jurídica, em contraposição a uma pretensa continuidade histórica com a suprassunção das categorias benjaminianas em novas sínteses. A análise qualitativa com revisão bibliográfica e técnica de análise de conteúdo, em especial das obras de Walter Benjamin, são as linhas metodológicas utilizadas; com o apoio das linhas interpretativas contemporâneas dos textos de Benjamin, realizadas por Giorgio Agamben e Slavoj Žižek. A título de conclusão, destaca-se o sentido emancipador da categoria violência divina - traduzida politicamente como greve revolucionária -, capaz de romper o tempo parasitário da violência mítica.
\end{abstract}

PALAVRAS-CHAVE: Institucionalidade jurídica. Crítica do direito. Violência mítica. Violência divina. Walter Benjamin.

\section{ABSTRACT}

The aim of this article is to reestablish the critique of legal institutionality from the categories of Walter Benjamin's essay "Zur kritic der Gewalt", 1921; more specifically, regarding the tension between the categories mythic violence - instituting and conservative of the law - and divine violence - depository of the juridical institutionality. The underlying hypothesis points to a break with historical and legal continuity, as opposed to an alleged historical continuity with the superseding of the Benjaminian categories into new syntheses. The qualitative analysis with bibliographical revision and content analysis technique, especially of the works of Walter Benjamin are the methodological lines used; with the support of the contemporary interpretative lines of the texts of Benjamin, realized by Giorgio Agamben and Slavoj Žižek. As a conclusion, the emancipatory sense of the category of divine violence - politically translated as a revolutionary strike - is capable of breaking the parasitic time of mythic violence. KEYWORDS: Legal institutionality. Critique of the law. Mythical violence. Divine violence. Walter Benjamin.

\footnotetext{
* Mestre e Bacharel em Direito pela Universidade de Caxias do Sul (UCS). Professor do curso de Direto da Universidade de Caxias do Sul. Membro do Núcleo de Estudos e Pesquisas em Políticas Públicas e Sociais (NEPPS).

** Doutor e Mestre em Ciência Política pela Universidade Federal do Rio Grande do Sul (UFRGS) e Bacharel em Ciências Sociais pela UFRGS. Professor Adjunto II da Universidade de Caxias do Sul (UCS). Membro do Núcleo de Estudos e Pesquisas em Políticas Públicas e Sociais (NEPPS).
}

Sapere aude - Belo Horizonte, v. 9 - n. 17, p. 100-118, Jan./Jun. 2018 - ISSN: 2177-6342 


\section{CONSIDERAÇÕES INICIAIS}

O ensaio de Walter Benjamin Zur Kritik der Gewalt ${ }^{1}$ (Para uma crítica da violência), publicado nos Archiv für Sozialwissenschaft und Sozialpolitik em 1921, constitui um de seus textos mais enigmáticos - quase esotérico - que trata da relação entre vida e política. $\mathrm{O}$ ensaio comporia um projeto maior, dividido em três partes: a primeira com título $O$ verdadeiro homem político; a segunda parte intitulada $A$ verdadeira política, que consistiria em uma antítese da primeira parte; e, por fim, uma terceira parte que não recebeu título, mas deveria estabelecer uma crítica da política a partir do romance Lesabéndio (1913) de Paul Scheerbart. O resultado desse projeto inconcluso foi apenas o texto Para uma crítica da violência, sendo que os outros dois textos podem ser considerados perdidos.

Com o objetivo fundamental de reestabelecer a crítica da institucionalidade jurídica por meio das categorias benjaminianas, o presente artigo busca analisar criticamente o binômio violência mítica/violência divina. De forma complementar, e para que seja conferida profundidade conceitual ao artigo, será cotejado o texto de Benjamin com a obra Reflexões sobre a violência (1908/1992) de Georges Sorel. Nesse sentido, a hipótese subjacente ao artigo consiste na assertiva de que as categorias desenvolvidas por Sorel são, no plano político, a cristalização dos conceitos político-teológicos de Benjamin.

A tematização leva em consideração o núcleo da crítica do direito, isto é, das instituições jurídicas como promotoras de violência. A partir da temática da crítica do direito, o artigo desdobra-se para a proposição de uma descontinuidade: a irrupção do tempo messiânico, ou seja, a ruptura do continnum pela violência divina - a subversão das forças de instauração e manutenção do status quo.

Pensar a violência institucional compõe uma necessidade na contemporaneidade, de tal forma que justifica-se na medida em que as instituições do direito e do Estado sofrem críticas e questionamentos. Por essa razão, revisitar Benjamin revela-se profícuo para o debate

\footnotetext{
1 A respeito do conceito empregado por Benjamin no título de seu texto - Gewalt -, há já nele uma rica pluralidade de sentidos, o que pode remeter a diversos significados, como poder (Macht), violência (Zwang), força (Stärke) e despotismo (gewaltherrschaft). Segundo Balibar (2009, p. 101) o termo Gewalt contém uma ambiguidade intrínseca: ele refere, ao mesmo tempo, à negação do direito e da justiça e à sua realização ou assunção de responsabilidade por eles por uma instituição (geralmente o Estado). O ensaio de Benjamin busca refletir sobre a dualidade poder/violência que o conceito de Gewalt expressa, e sua relação com o direito. Segundo Seligmann-Silva, o título do texto de Benjamin já reflete que a "'indecidibilidade' que está no coração do termo alemão Gewalt, que significa tanto poder quanto violência (e afirma que um não existe sem o outro), já contém in nuce o centro da argumentação benjaminiana." (SELIGMANN-SILVA, 2005, p. 25, grifo do autor).
}

Sapere aude - Belo Horizonte, v. 9 - n. 17, p. 100-118, Jan./Jun. 2018 - ISSN: 2177-6342 
e para a reflexão a respeito do destino das instituições jurídicas contemporâneas, em tempos de ódio e violência.

\section{VIOLÊNCIA MÍTICA: A INSTITUCIONALIDADE JURÍDICA}

O ensaio Para uma crítica da violência foi o resultado de pesquisas realizadas por Benjamin acerca da relação entre vida, violência e política. À época, Benjamin estava profundamente influenciado pelo texto O espírito da utopia (1918) de Ernst Bloch, além de inquietações a respeito de uma possível legitimidade que a violência revolucionária poderia aspirar - inquietações que, segundo Honneth (2009, p. 101), emergiram justamente em virtude da revolução russa de 1917 e a alemã de 1918.

O objetivo do ensaio de Benjamin não é de forma alguma refletir sobre o lugar da violência no direito moderno, mas de estabelecer um diagnóstico crítico a seu respeito, de modo a encontrar uma forma de violência de índole tão subversiva que possuísse a capacidade de deposição da violência que instaura e conserva a institucionalidade jurídica. Essa é a mesma interpretação de Agamben (2004, p. 84) quando afirma que "o objetivo do ensaio é garantir a possibilidade de uma violência [...] absolutamente 'fora' (ausserhalb) e 'além' (jenseits) do direito e que, como tal, poderia quebrar a dialética entre violência que funda o direito e violência que conserva".

O ensaio está profundamente influenciado pela formação intelectual de juventude de Benjamin, a qual se caracteriza por opor-se à caída do tempo presente no pensamento utilitário e instrumental, ou seja, de meios e fins (HONNETH, 2009, p. 103). Para Benjamin, o mal essencial da sociedade contemporânea é tratar todos os assuntos a partir do cálculo instrumental de meios e fins; e em face à caída da cultura no cálculo instrumental, se oporia a proposta de uma formação cultural autorreferente ${ }^{2}$ e reflexiva, que se assemelha a Deus diante de sua capacidade divina de subtração de toda finalidade. A contrariedade à instrumentalização do pensamento pelo cálculo de meios e fins demonstra a posição de Benjamin marcada por uma filosofia da religião e por sua formação na moral kantiana.

\footnotetext{
2 A esse respeito, o texto Sobre a linguagem em geral e sobre a linguagem do homem (BENJAMIN, 2011) demonstra a posição do autor a respeito da queda da linguagem adâmica, linguagem paradisíaca - que comunica a si mesma - para a linguagem humana, babélica, ou ainda, burguesa - que estabelece uma relação entre meios e fins.
} 
Além disso, é possível distinguir a influência transversal do texto Espírito da utopia de Ernst Bloch no ensaio de Benjamin, em razão da carga escatológica conferida ao conceito de revolução marxista. A classe proletária é igualmente depositária das esperanças e energias religiosas como o sinal intramundano no retorno de Deus. A influência de Bloch sobreviveu em toda a obra de Benjamin, porém, de modo especial no conceito de "violência divina" do ensaio. Outras influências imediatas foram Charles Péguy, Georges Sorel e Erich Unger, e embora os distintos autores perfilem divergências em suas obras, há uma ideia compartilhada por todos: o antiutilitarismo - que visualiza o político não como um meio para um fim, mas como uma moral visionária (HONNETH, 2009, p. 104).

A concepção antiutilitarista, que compreende a relação "meios e fins", é norteadora do ensaio Para uma crítica da violência, ensaio esse no qual Benjamin estabelece uma análise oposta à tradição política até então: na tradição moderna, toda a política encontra seu limite na violência, e tem como ponto de partida o direito; porém, em seu texto, Benjamin inverte essa ordem ao estabelecer a violência como fonte, e o direito como o término do político. Nas interpretações de Berdet (2014, p. 117), Benjamin parte da distinção entre as duas grandes linhas teóricas do direito: o direito natural e o direito positivo, e em seguida opõe violência ilegal e legal na qual a violência legal é fundadora e mantenedora do direito, para então, mostrar a cumplicidade entre ambas as categorias (BENJAMIN, 2011, p. 121).

A questão inicial proposta por Benjamin diz respeito às relações entre direito e justiça sob o prisma do direito natural e do direito positivo. Benjamin afirma que tanto os fins justos perseguidos pelo direito natural são mediados pela violência, como também os meios justos, perseguidos pelo direito positivo (BENJAMIN, 2011, p. 122). Seus critérios de legitimidade são construídos retroativamente a partir da relação entre meios e fins ${ }^{3}$ - esta é a

\footnotetext{
3 É claro que a relação mais elementar e fundamental de toda ordem de direito é aquela entre fim e meios. Além disso, que, em princípio, a violência só pode ser procurada na esfera dos meios, não dos fins. Com estas constatações obtêm-se mais aspectos para a crítica da violência e, todavia, talvez diferentes do que pode parecer à primeira vista. Pois, se a violência for um meio, então parece haver, sem mais, um critério para a sua crítica. Este se impõe na pergunta se a violência é em determinados casos meio para fins justos ou injustos. Sendo assim, sua crítica estaria implicitamente dada em um sistema de fins justos. Mas não é bem assim. Pois o que tal sistema incluiria - aceitando-se a hipótese de que estivesse assegurado contra todas as dúvidas - não é um critério da violência em si mesmo enquanto princípio, mas um critério para os casos de sua aplicação. Permaneceria ainda sempre aberta a questão se a violência em geral, enquanto princípio, é ética, mesmo como meio para fins justos. Desse modo, esta pergunta necessita para sua decisão de um critério mais preciso, de uma diferenciação na esfera dos próprios meios, sem consideração pelos fins aos quais servem. (BENJAMIN, 2011, p. 122-123).
} 
ideia subjacente: a de que em todos os ordenamentos jurídicos a relação basilar é de meios e fins (BENJAMIN, 2011, p. 122).

A máquina jurídica do poder-violência constitui uma relação toda especial entre meio e fim, visto que põe a manifestação imediata da violência como meio fundador do direito, cujo fim é instituir o direito como um poder profundamente aferrado à violência institucionalizada (mediatizada juridicamente). (SILVA JÚNIOR, 2017, p. 58).

Diante disso, as duas tradições jurídicas analisadas por Benjamin possuem um pressuposto em comum: a relação de meios e fins como critério supremo para julgar a violência do direito. Ao levar esse pressuposto em consideração, o direito positivo seria "cego para o caráter incondicional dos fins" - pois todos os fins devem ser garantidos pelos meios e o direito natural é igualmente cego "para o caráter condicional dos meios" -, um exemplo dessa cegueira foi a justificação ideológica da fase do Terror na Revolução Francesa pelo direito natural (BENJAMIN, 2011, p. 124).

Em seguida, Benjamin estabelece a dualidade entre a violência de origem mítica e a violência de origem divina. Enquanto a primeira instaura e conserva o direito - é poder constituinte e constituído; a segunda é oriunda da greve geral revolucionária como forma de poder que depõe o direito e instaura um novo tempo histórico (BERDET, 2014, p. 118). A deposição do direito pela violência divina significa a destruição de toda forma de poder sobre a vida, ou seja, destruição da mera vida ${ }^{4}$ (das blossen Leben) como vida meramente natural presa à sua imanência orgânica culpada e sem liberdade (GAGNEBIN, 2014, p. 54).

A passagem do direito natural e positivo para a violência mítica leva em consideração a relação constitutiva de meios e fins do fenômeno jurídico. Por outro lado, a passagem da violência mítica para o aprisionamento da mera vida em sua imanência natural decorre das estruturas coercitivas do direito, ou seja, de sua institucionalização da culpa. A esse respeito, Benjamin designa "tempo parasitário" para referir-se ao tempo que não conhece o presente, pois iguala-se a outro tempo que já passou. O tempo do direito é um tempo que não é autônomo, que "parasita" um outro tempo, o tempo de uma vida superior - de uma vida “sobrenatural" (BENJAMIN, 2016, p. 54).

4 Segundo Gagnebin (2014, p. 55) o termo utilizado por Benjamin é das blosse Leben, que pode ser traduzido como mera vida. O adjetivo bloss tem o sentido de "mero", "simples", "sem nenhum suplemento". Ao contrário do termo nackt que significa "nu" no sentido de "despido" em oposição a "coberto". Portanto, é questionável a partir de um ponto de vista filológico a aproximação que Agamben faz do termo vida nua com o termo mera vida de Benjamin. 
Essa temporalidade parasitária do direito - que é também o tempo do mito - é o tempo do destino, da "repetição" ou do "eterno retorno". Esse tempo está preso ao status quo, pois está destinado a uma infinita repetição do mesmo, em uma identidade com aquilo que já foi - ele nada sabe a respeito do passado, em vista de que o passado é igual ao mesmo, ao que vem depois. Esse tempo parasitário igualmente nada sabe do futuro, pois ele será sempre o que já é. 'Desse modo, sua não autonomia como sinônimo de 'repetição' interdita ao tempo do destino toda espécie de consideração acerca da liberdade e autodeterminação possíveis aos indivíduos. Aos que se deixam reger por ele, longe está a conquista da 'maioridade'." (CHAVES, 1994, p. 22).

O tempo mítico, do eterno retorno, é o tempo do direito que está enclausurado no presente, ainda que não o conheça, por não poder distingui-lo do passado ou do futuro. $\mathrm{O}$ tempo do direito, que é o tempo do destino, repete sempre o mesmo e impossibilita com que se rompa com o progresso da história. Esse tempo de repetição impede que o sujeito se torne autônomo e livre para uma escolha moral, e é nesse sentido que a violência mítica, isto é, a violência instauradora e conservadora do direito, aprisiona os sujeitos em uma forma de vida culpada (mera vida), própria de uma temporalidade parasitária, cujo sentido primordial é o da repetição. Em consequência, a vida torna-se presa à sua imanência natural e sem liberdade para a ética - a liberdade de escolha.

A esse respeito, Gagnebin (2014, p. 54) afirma que "na ordem mítica do destino, o homem é culpado - por definição; ou seja, pelo simples fato de estar vivo, entregue a um jogo de forças de naturezas diversas que ele pode tão só reconhecer (como Édipo no final da tragédia).”. Na esfera do mito o homem está condenado pelo destino a uma vida culpada, dessa forma, estabelecer uma crítica do mito não é apenas o estabelecimento de uma crítica "de certo momento vivido pela humanidade, mas significa a crítica de uma concepção de vida e de destino que sempre ameaça, sob formas diversas, as tentativas humanas de agir histórico e livremente" (GAGNEBIN, 2011, p. 9).

O que Benjamin busca afirmar é que a temporalidade reproduzida pelo império da lei é uma temporalidade que impede os sujeitos de escolhas livres, ao impingir-lhes a violência reproduzida pela institucionalidade jurídica (VIEIRA, 2016, p. 47). O futuro não é visto como algo qualitativamente diferente e, portanto, melhor; ele será sempre o mesmo, a manutenção do status quo. Assim, as instituições destacadas por Benjamin a respeito da dialética entre instauração e conservação do direito são: a violência de guerra, o militarismo, a polícia, a 
pena de morte e os tratados de paz. O que todas essas instituições jurídicas têm em comum é a possibilidade de serem usadas como forma de manutenção do próprio direito.

A crítica de Benjamin à temporalidade do direito tem como foco a estrutura temporal da forma jurídica, indicando de que maneira ela produz e reproduz a concepção temporal hegemônica da modernidade: vazia, linear, homogênea e pautada no progresso como curso inexorável da história. A norma jurídica é formada para uma intervenção seletiva sobre determinadas práticas sociais, objetivando reproduzir e perpetuar um futuro idealizado daquela norma enquanto progresso (vide as normas programáticas da Constituição Federal de 1988). Benjamin está igualmente interessado em questionar de que forma a intervenção seletiva sobre a realidade pela norma jurídica contribui para estabilizá-lo e conservá-lo, de forma a garantir um determinado estrato de relações de poder. Dessa forma, a crítica de Benjamin é uma crítica do poder jurídico (violência mítica) que impõe uma determinada ordem de destino, cujo contraponto é a revolução (violência pura) como ato histórico-político capaz de romper com a temporalidade mítica. (VIEIRA, 2016, p. 46-47).

No entanto, importa ressaltar que Benjamin concentra sua crítica em determinadas tendências estruturais de funcionamento do direito na modernidade, e de forma alguma sua crítica possui um tom geral, abstrato e, consequentemente, vago. Benjamin, ao contrário, indica a necessidade de superar a forma jurídica através de uma crítica às principais instituições do direito que exercem diretamente a manutenção da violência soberana. A crítica de Benjamin é uma crítica à violência soberana (mítica), e não uma crítica moral da violência em sentido abstrato (moralismo). A violência soberana é uma violência organizada, institucionalizada, sistemática e legitimada pelo poder do Estado. Além disso, a violência por parte do oprimido em direção ao opressor é vista por Benjamin como legítima, além de capaz de transformar-se em ação política que é capaz de romper com a dialética da violência institucional.

Contudo, a ação política da violência divina - a greve geral proletária -, como destruição das formas de poder sobre a vida é, ao contrário da violência mítica, não sangrenta. A violência divina não ataca sujeitos, mas instituições (BENJAMIN, 2011, p. 150). A violência divina se aproxima do que Luxemburgo (2011, p. 291) afirmou a respeito da revolução proletária: “ela [a revolução proletária] não precisa do terror para realizar seus fins, ela odeia e abomina o assassinato. Ela não precisa desses meios de luta porque não combate indivíduos, mas instituições”. 
É em meio a esse diagnóstico que Benjamin recupera as reflexões do teórico anarcosindicalista Georges Sorel, especialmente da obra Reflexões sobre a violência, de 1908. Sorel posiciona-se a favor de uma visão pessimista e catastrófica da história ao afirmar que o "pessimista vê as condições socais formando um sistema encadeado por uma lei implacável, cuja necessidade deve ser suportada, tal como ela é dada em bloco e que só poderia desaparecer com uma catástrofe que a arrastasse por inteiro” (SOREL, 1992, p. 32). Essa posição pessimista e catastrofista é compartilhada por Benjamin.

Para Sorel, após a fase revolucionária da classe burguesa, houve um período de construções ideológicas de consensos na união entre capital e trabalho - o mesmo fenômeno de decadência por parte da classe burguesa que Lukács diagnosticou em sua obra $A$ destruição da razão; nesse sentido, e diante dos consensos criados pela ideologia burguesa a respeito da democracia-liberal, Sorel observa que a única forma de transformação social é uma ativação da luta de classes adormecida: a violência proletária é necessária para reavivar a ferocidade burguesa e, em última instância, chamar as classes a exercerem seu papel histórico (SOREL, 1992, p. 103). Investe-se na violência proletária para quebrar displicência democrática do final do século XIX e início do século XX (BIER, 2013, p. 209).

Por meio dessa perspectiva vitalista, Sorel se opõe às correntes do humanismo socialistas de Estado: a social-democracia. Sua oposição é acentuada diante do ranço estatista que o pensamento marxista trazia a respeito da revolução: havia a necessidade de uma ditadura do proletariado (BIER, 2013, p. 209). Para Sorel, contudo, a violência proletária era a única capaz de empreender uma descontinuidade, isto é, única capaz de destituir por meio de um abalo sísmico social a dialética entre os poderes constituintes e conservadores do direito. Deve-se levar em consideração que o direito burguês busca a pacificação dos conflitos com a ampliação dos direitos dos trabalhadores e, por essa razão, constitui um elemento ideológico por excelência (ALTHUSSER, 1999, p. 102). Contra a opacidade da luta de classes, Sorel afirma que

A violência proletária não só pode garantir a revolução futura, como parece ser também o único meio de que dispõem as nações europeias, embrutecidas pelo humanitarismo, para reencontrar sua antiga energia. Essa violência força $o$ capitalismo a se preocupar unicamente com seu papel material e tende a devolverlhe as qualidades belicosas que possuía outrora. (SOREL, 1992, p. 103-104). 
A proposta de Sorel - diante de sua aversão à social-democracia que, através da greve geral política, apenas busca barganhar um etapismo inefetivo - é trazer a burguesia de volta às armas. A busca pela ativação da violência proletária é a forma de instigar a burguesia a revestir-se novamente de seu ímpeto e ferocidade revolucionários. "O que pode soar como um tenebroso apelo à guerra é, para o autor francês, uma necessidade histórica ante o amordaçamento da luta de classes frente ao império do reformismo através da força.” (BIER, 2013, p. 211).

Diante disso, Benjamin encontrará por meio das reflexões de Sorel a respeito da greve geral proletária sua matéria prima para seu conceito de "violência divina". No ensaio de Benjamin há uma desconstrução da violência legal e uma reabilitação da violência divina ou pura, de inspiração anarquista (LÖWY, 1983, p. 782) e que poderia livrar a humanidade da injustiça ao romper com a institucionalidade jurídica, isto é, com a violência mítica.

Nesse momento, a análise benjaminiana reflete acerca dos antagonismos que existem entre o sujeito e a lei, ao constatar uma contradição: enquanto por parte dos indivíduos a violência é sempre natural - no sentido de que é sempre exterior ao direito, e por isso, lhe é uma ameaça constante -, para o direito não existem fins naturais. "Poderia se dizer que um sistema de fins de direito torna-se insustentável se em algum lugar ainda se permite que fins naturais sejam perseguidos de maneira violenta.” (BENJAMIN, 2011, p. 127).

Os "fins naturais" de que fala Benjamin são aspirações que os sujeitos possuem de transformação das relações sociais não previstas no ordenamento jurídico, como reformas e revolucionamento. Em razão dessas aspirações de transformação das relações sociais, o direito positivo busca o monopólio da violência e, ${ }^{5}$ desse modo, coloca limites na ação dos indivíduos ao cercear a busca por fins naturais. Somente para o direito é possível alcançar fins por meios violentos, sendo que aos indivíduos não cabe buscar seus fins utilizando-se de violência. Portanto, o direito monopoliza a violência não para garantir os fins do direito, mas para garantir sua própria existência, a perpetuação de seu status quo (BENJAMIN, 2011, p. 126).

5 A respeito disso, Matos (2012, p. 305) destaca que "não há qualquer sentido na tentativa de definir o direito mediante certo plexo de valores agrupados sob o signo altamente indeterminado da justiça. Tanto é assim que ao direito positivo pouco importa se outras ordens normativas - postas por um grupo de criminosos ou por um partido revolucionário, por exemplo, - objetivam com suas ações certas finalidades que podem se razoavelmente definidas como justas. Na verdade, o que o direito não suporta é que ordenações concorrentes tendam a interferir em sua monopolização da violência. Em síntese: pouco importa a justeza de certa reivindicação coletiva; importa apenas se ela se aparelha ou não mediante o uso da violência, monopólio da ordem jurídica". 
[...] talvez se devesse levar em conta a possibilidade surpreendente de que o interesse do direito em monopolizar a violência com relação aos indivíduos não se aplicaria pela intenção de garantir os fins do direito mas, isso sim, pela intenção de garantir o próprio direito; de que a violência, quando não se encontra nas mãos do direito estabelecido, qualquer que seja este, o ameaça perigosamente, não em razão dos fins que ela quer alcançar, mas por sua mera existência fora do direito. (BENJAMIN, 2011, p. 127).

A dialética entre as forças que instauram e conservam o direito monopoliza a violência (fins naturais) com relação aos indivíduos para assegurar a manutenção do status quo, pois não pode haver violência contra e fora do Estado. Nesse sentido, a violência mítica - que instaura e conserva o direito - busca indicar o exercício de um tipo de violência desempenhada pelo Estado por meio de instituições jurídicas que busca manter o status vinculativo da lei sobre os sujeitos. Em outras palavras, a violência mítica é a violência soberana e legal que mantém a legitimidade e a aplicabilidade da lei, além do sistema de punição (tribunais) quando a lei for desrespeitada, e as formas de responsabilidade legal que asseguram a permanência forçosamente obrigada de os indivíduos agirem de acordo com a lei (BUTLER, 2006, p. 204).

A violência mítica é, portanto, uma força coercitiva que emana da institucionalidade jurídica e impede que os sujeitos desenvolvam um ponto de vista crítico, se não revolucionário, sobre essa mesma institucionalidade jurídica (BUTLER, 2006, p. 202-205). Como anteriormente afirmado, a violência mítica desdobra-se em dois tipos de violência: a violência que instaura (rechtsetzend) e a violência que conserva o direito (rechtserhaltend). (BENJAMIN, 2011, p. 132), sendo operacionalizadas através de instituições como: o parlamento, a violência de guerra, a polícia, o militarismo, a pena de morte e os tratados de paz. Assim, a violência que conserva o direito é exercida tanto pela polícia, como pelo militarismo e pela pena de morte, e representa esforços repetitivos e institucionalizados para garantir que a lei continue a ser vinculativa para a população. A violência que instaura o direito é exercida pela violência de guerra, e a instauração e criação de um novo direito é sancionada pelos tratados de paz.

Diante disso, a proposta de uma violência subversiva que rompa com a institucionalidade jurídica é a proposta de Benjamin, ao absorver as reflexões de Sorel como um importante estímulo à crítica do direito e do marasmo político, incentivando o acirramento de tensões entre a classe burguesa e a classe proletária. Porém, o ponto focal do texto benjaminiano é a ruptura com a violência mítica, que instaura e conserva o direito. A proposta 
de Benjamin consiste na elaboração de uma violência subversiva, capaz de irromper uma descontinuidade sem a instauração de uma nova institucionalidade jurídica. A violência divina é a categoria benjaminiana para buscar tal ruptura e descontinuidade, expiando a vida culpada - a mera vida.

\section{DESCONTINUIDADE: A VIOLÊNCIA DIVINA E A DEPOSIÇÃO DO DIREITO}

Em seu texto Reflexões sobre a violência, Sorel estabelece a divisão entre greve geral política e greve geral revolucionária, a qual Benjamin utilizará para desenvolver sua argumentação a respeito da violência pura como um meio sem um fim (medialidade) capaz de subverter a violência da institucionalidade jurídica (SOREL, 1992, p. 172 et seq.). Enquanto a greve geral política caracteriza-se pela busca de mais direitos, a greve geral proletária é insurrecional, inerentemente contestadora do status quo e, em razão disso, busca o revolucionamento da institucionalidade jurídica.

Nesse sentido, a greve geral política não se opõe à violência mítica que instaura e conserva o direito, ao contrário, endossa uma postura que conserva as coordenadas do Estado de direito (SOREL, 1992, p. 173). A greve geral proletária, por outro lado, busca a própria deposição do direito e a instauração de um novo tempo histórico. A violência mítica, portanto, se opõe à violência divina assim como "Deus se opõe ao mito, a violência divina [pura] se opõe à violência mítica" (BENJAMIN, 2011, p. 150).

\footnotetext{
Se a violência mítica é instauradora do direito, a violência divina é aniquiladora do direito; se a primeira estabelece fronteiras, a segunda aniquila sem limites; se a violência mítica traz, simultaneamente, culpa e expiação, a violência divina expia a culpa; se a primeira é ameaçadora, a segunda golpeia; se a primeira é sangrenta, a divina é letal de maneira não sangrenta. (BENJAMIN, 2011, p. 150).
}

Na passagem citada, Benjamin deixa clara a oposição entre violência mítica e violência pura. Enquanto a primeira se operacionaliza através de instituições jurídicas, a violência divina/pura é operacionalizada através da greve geral proletária - pois é uma violência que está fora do direito. No entanto, a postura dos socialistas moderados da obra de Sorel é idêntica à postura dos social-democratas da obra de Benjamin: ambos grupos são adeptos da greve geral política, e ambos são criticados pelos autores por serem incapazes de 
questionar radicalmente as relações capitalistas, promovendo apenas mudanças no poder do Estado (VIEIRA, 2016, p. 84).

Por outro lado, a greve geral proletária busca superar o Estado e depor a violência mítica reproduzida pelo direito através de suas instituições. “A greve geral proletária se propõe, como única tarefa, aniquilar o poder do Estado.” (BENJAMIN, 2011, p. 142). A greve geral é considerada por Benjamin como "anarquista" - embora não um anarquismo ingênuo e, na esteira do pensamento de Marx (2012) e posteriormente reiterado por Pachukanis (2017), rejeita qualquer forma de institucionalização jurídica. Assim como o jurista russo, Benjamin era um dos autores que rejeitava a própria forma jurídica.

Mas em resposta à proposta subversiva de Benjamin, a violência mítica combate a greve geral proletária qualificando-a como uma violência fora e além do direito, como um fim natural dos homens. O combate da greve geral proletária pela violência mítica é a luta pela conservação do status quo da institucionalidade jurídica, do próprio direito em si - único capaz de utilizar a violência. Mas a possibilidade do aniquilamento da violência mítica é reiterada pela figura da violência pura (reine Gewalt) ou divina e, na esfera humana, pela violência revolucionária (AGAMBEN, 2004, p. 84). Embora dificilmente o direito à greve possa ser visto como violência, e talvez seja essa a razão de ele ter sido concedido ao proletariado, o operariado ainda é o único sujeito jurídico - além do Estado - ao qual se concede a violência insurrecional (NASCIMENTO, 2017, p. 127).

Já no texto A vida dos estudantes de 1915, seguindo as pegadas de Nietzsche, Benjamin esboça sua crítica do progresso e da visão científica da história realizada pelo historicismo, sobretudo o historicismo neokantiano. A visão linear e contínua da história é uma visão mecanicista que coloca os fatos e as relações em um tempo homogêneo que conduz em direção ao futuro (JAREK, 2016, p. 63). A consequência dessa visão teleológica, mecânica e progressista da história é a simplificação da experiência da temporalidade nos indivíduos e, para Benjamin, simplificar a temporalidade é restringir a experiência que os indivíduos podem ter em suas vidas.

A crítica do progresso ${ }^{6}$ está igualmente presente no ensaio Para uma crítica da violência, que aparece sob a crítica do direito - seja pelo direito natural, seja pelo direito positivo - ao buscar uma ação não teleológica, um meio sem um fim. A violência pura

6 "Deve-se fundar o conceito de progresso na ideia de catástrofe. Que tudo continue assim. Isto é a catástrofe. Ela não é o sempre iminente, mas sim o sempre dado" (BENJAMIN, 2009, p. 515). 
enquanto greve geral proletária (revolucionária) é um meio sem fim que rompe com a linearidade do progresso histórico, com a cadeia temporal cujos sujeitos estão presos e inaugura um novo tempo histórico, o tempo do agora (Jetztzeit) que compreende novas relações humanas e de trabalho. A ruptura com o tempo histórico é revolucionária, segundo Löwy, "Marx havia dito que as revoluções são a locomotiva da história mundial. Mas talvez as coisas se apresentem de maneira completamente diferente. É possível que as revoluções sejam o ato, pela humanidade que viaja nesse trem, de puxar os freios de emergência" (LÖWY, 2005, p. 93-94).

A violência pura (reine Gewalt) não está inscrita sob o signo de meios e fins próprios da violência mítico-jurídica, que é instrumental; a violência pura é não teleológica e, por isso, não está vinculada a uma ordem temporal regida pela relação meios e fins que justifica a violência soberana e, por consequência, as desigualdades. "A violência pura irrompe o ciclo de reprodução e a teleologia presentes na concepção de história subjacentes à ordem jurídica, inaugurando a possibilidade de um tempo distinto." (VIEIRA, 2016, p. 87). A respeito da dualidade violência pura e violência mítica:

\begin{abstract}
Assim como em todos os domínios Deus se opõe ao mito, a violência divina se opõe à violência mítica. E de fato, estas são contrárias em todos os aspectos. Se a violência mítica é instauradora do direito, a violência divina é aniquiladora do direito; se a primeira estabelece fronteiras, a segunda aniquila sem limites; se a violência mítica traz, simultaneamente, culpa e expiação, a violência divina expia a culpa; se a primeira é ameaçadora, a segunda golpeia; se a primeira é sangrenta, a divina é letal de maneira não sangrenta. (BENJAMIN, 2011, p. 150).
\end{abstract}

Por não estar inscrita sob o signo da instrumentalidade a violência pura é constituída por sua medialidade sem fim e afirma sua necessidade de subversão da ordem mítico-jurídica, e por consequência, da remissão dos oprimidos pelo destino e pela vida culpada. Nesse momento é necessário esclarecer que a deposição do direito é para Benjamin um evento histórico e político, não metafísico - ainda que escatológico. Segundo Hamacher (1997, p. 128) "trata-se, contudo de um evento que [se o]põe à história cíclica das instituições legais e que não é inteiramente determinado por essa mesma história. A deposição é um evento político, mas um evento que despedaça todas as determinações canônicas do político".

No momento, cabe a questão: o que é uma violência que não instaura o direito? O esboço de uma resposta pode ser lida no artigo Sobre os limites da violência de Agamben publicado em 1969. Em resposta a tal questão, Agamben faz lembrar a "violência sacra" dos 
povos primitivos. Segundo Agamben a quase totalidade dos povos primitivos conhecem "rituais violentos cuja celebração busca interromper o fluxo homogêneo do tempo profano e, reatualizando o caos primordial, permitir ao homem, tornando-o novamente contemporâneo de deus, atingir a dimensão original da criação" (AGAMBEN, 1969, p. 168, tradução nossa). É o que os gregos expressam na figura de Dionísio e sua característica de morrer e de renascer.

Na proximidade entre vida e morte é que a violência sacra - destaca Agamben - deve ser situada. A esse respeito, Hegel já afirmara que "o princípio conceitual de que toda a violência destrói a si mesma possui a sua real manifestação no fato de uma violência se anular com outra violência" (HEGEL, 1997, p. 84). No mesmo sentido Marx afirma n’ A ideologia alemã que:

a revolução, portanto, é necessária não apenas porque a classe dominante não pode ser derrubada de nenhuma outra forma, mas também porque somente com uma revolução a classe que derruba detém o poder de desembaraçar-se de toda a antiga imundície e de se tornar capaz de uma nova fundação da sociedade. (MARX; ENGELS, 2007, p. 42).

O que Agamben procura afirmar é que a violência pura pressupõe uma relação entre o velho e o novo, entre a vida e a morte: é necessário antes morrer para que seja possível renascer. A violência pura possui a característica de destruir a si mesma, ela é a violência "que na negação do outro faz a experiência da própria autonegação e na morte do outro leva à consciência sua própria morte"7 (AGAMBEN, 1969, p. 170, tradução nossa). Apenas a violência revolucionária é portadora da consciência da necessidade de sua própria negação (negação de si), somente ela é capaz de reivindicar uma interrupção messiânica do tempo; isto é, do próprio continuum da história. Com essa passagem, Agamben indica que a violência pura/revolucionária de Benjamin está próxima à revolução de classe de Marx - em que o ato revolucionário experimenta sua própria negação dialética como classe.

\footnotetext{
7 Segue a citação completa: "Não a violência que é simplesmente meio ao fim justo da negação do sistema existente, mas a violência que na negação do outro faz a experiência de sua própria autonegação e na morte do outro traz a consciência da sua própria morte, é a violência revolucionária. Somente enquanto é portadora desta consciência, somente enquanto, isto é, está de fronte à ação violenta saberá que é essencialmente a sua morte que está em questão. A classe revolucionária adquire não o direito, mas, acima de tudo, assume o terrível compromisso de recorrer à violência. Como a violência sacra, a violência revolucionária é antes de tudo paixão, no sentido etimológico da palavra, autonegação e sacrifício de si." (AGAMBEN, 1969, p. 170, tradução nossa, grifos do autor).
} 
Portanto, a violência pura é aniquiladora do direito e nela não há qualquer pretensão de institucionalização jurídica. O messianismo benjaminiano - o qual se vincula com o conceito de violência pura/divina - possui um elemento destrutivo em seu porvir escatológico. O elemento destrutivo do messianismo representa a destruição da ordem injusta, e não de indivíduos particularizados, ou seja, o messianismo de Benjamin representa uma ruptura com a violência mítico-jurídica e soberana, ele é "uma força no mundo, não apenas um devir. Em outras palavras, não é algo do talvez, mas sempre algo que irrompe no mundo, no aqui e no agora de uma forma muito tangível e de um modo bastante real" (MARTEL, 2012, p. 33, tradução nossa).

A violência divina é ato político. Ela não "governa ou executa (die schaltende), mas [...] simplesmente age e se manifesta (die waltende)" (AGAMBEN, 2004, p. 96). No mesmo sentido de Agamben, Žižek apresenta sua contribuição interpretativa ao conceito benjaminiano de violência divina. $\mathrm{O}$ autor esloveno identifica a violência divina com eventos históricos positivamente existentes: o Terror revolucionário de 1792-1794, como também o Terror Vermelho de 1919 e, por que não, a Comuna de Paris de 1871. Para Žižek a violência divina coincide com o dispositivo biopolítico dos Homines Sacri: "em ambos os casos, matar não é um crime nem um sacrifício" (ŽIŽEK, 2014, p. 155).

Por outro lado, a violência divina, ainda segundo Žižek (2014, p. 116), não consiste em uma intervenção direta de Deus onipotente vindo punir a humanidade por seus pecados. "A violência divina deveria ser assim concebida como divina no sentido preciso do velho adágio latino vox populi, vox dei: [...] no sentido de uma assunção heroica da solidão da decisão soberana.” (ŽIŽEK, 2014, p. 157).

Acima de tudo, a violência divina opõe-se à violência mítica. Enquanto uma instaura, a outra depõe o direito e sua institucionalidade conservadora. A violência é, portanto, ato político - greve geral proletária, e não greve política. Sendo assim, Žižek afirma diante da IX tese sobre o conceito de história ${ }^{8}$ : “e se a violência divina fosse a intervenção selvagem nesse

8 "Há um quadro de Klee intitulado Angelus novus. Representa um anjo que parece preparar-se para se afastar de qualquer coisa que olha fixamente. Tem olhos esbugalhados, a boca escancarada e as asas abertas. $\mathrm{O}$ anjo da história deve ter esse aspecto. Voltou o rosto para o passado. A cadeia de fatos que aparece diante dos nossos olhos é para ele uma catástrofe sem fim, que incessantemente acumula ruínas sobre ruínas e lhas lança aos pés. Ele gostaria de parar para acordar os mortos e reconstruir, a partir dos seus fragmentos, aquilo que foi destruído. Mas do paraíso sopra um vendaval que se enrodilha nas suas asas, e que é tão forte que o anjo já não as consegue fechar. Esse vendaval arrasta-o imparavelmente para o futuro, e que ele volta as costas, enquanto o monte de ruínas à sua frente cresce até o céu. Aquilo a que chamamos o progresso é este vendaval." (BENJAMIN, 2016, p. 147). 
anjo? Ao ver o amontoado de escombros que cresce em direito ao céu, esses destroços de injustiça [...]” (ŽIŽEK, 2014, p. 157). Se toda a história da humanidade for a história dos vencedores sobre os vencidos, da acumulação do sofrimento de homens e mulheres sem rostos e sem nome, da normatização da injustiça, então a violência divina de Benjamin assemelhar-se-á à antevisão de Agamben sobre a inoperosidade do direito: "um dia, a humanidade brincará com o direito, como as crianças brincam com os objetos fora de uso, não para devolvê-los a seu lugar canônico, e sim, para libertá-los definitivamente dele" (AGAMBEN, 2004, p. 98).

\section{CONSIDERAÇÕES FINAIS}

A proposta de uma reflexão a respeito do pensamento de Walter Benjamin mostra-se, acima de tudo, contemporânea. Sintoma de sua atualidade é as consecutivas reinterpretações dadas a seus ensaios, em especial ao texto analisado, Para uma crítica da violência reabilitado especialmente pelas análises de Jacques Derrida, Giorgio Agamben e, recentemente, Slavoj Žižek.

A proposta do texto de Benjamin é uma análise crítica da violência mítica, instauradora e conservadora das instituições jurídicas para, em seguida, contrapor-lhe o conceito de violência divina/pura, de caráter subversivo e detentor da capacidade de deposição da institucionalidade jurídica: trata-se de verdadeiro ato político revolucionário. A violência de meios e fins é superada por uma violência divina, autorreferente e a-instrumental. A contraposição de conceitos por parte de Benjamin não busca uma suprassunção dialética, mas uma ruptura, isto é, uma descontinuidade do percurso histórico através da irrupção escatológica.

Com isso, a violência divina combate o tempo histórico parasitário do direito, o aprisionamento da mera vida em sua imanência culpada, ou seja, sem a liberdade de crítica do status quo. Trata-se de alimentar uma potência revolucionária, anti-institucional, que irrompa com as estruturas coercitivas do direito - reprodutoras da dominação de classe. Essa violência subversiva é, contudo, não sangrenta, pois não se dirige a indivíduos concretos, mas a instituições; a violência divina combate instituições reprodutoras do sempre-idêntico - porém não um combate metafísico, mas concreto e histórico: ela é ato político revolucionário. 
Artigo: Entre violência mítica e violência divina: a deposição da institucionalidade jurídica em Walter Benjamin

\section{REFERÊNCIAS}

AGAMBEN, G. Estado de exceção. Tradução de Iraci D. Poleti. São Paulo: Boitempo, 2004.

AGAMBEN, G. Sui limiti dela violenza. Nuovi Argomenti, n. 11, p. 160-173, 1969.

ALTHUSSER, L. Sobre a reprodução. Petrópolis, RJ: Vozes, 1999.

BALIBAR, É. Reflections on gewalt. Historical materialism, n. 17, 2009.

BENJAMIN, W. O anjo da história. Tradução de João Barreto. 2. ed. Belo Horizonte: Autêntica, 2016.

BENJAMIN, W. Escritos sobre mito e linguagem (1915-1921). Tradução de Susana Kampff Lages e Ernani Chaves; organização, apresentação e notas de Jeanne Marie Gagnebin. São Paulo: Editora 34, 2011.

BENJAMIN, W. Para uma crítica da violência. In: BENJAMIN, W. Escritos sobre mito e linguagem (1915-1921). Tradução de Susana Kampff Lages e Ernani Chaves; organização, apresentação e notas de Jeanne Marie Gagnebin. São Paulo: Editora 34.

BENJAMIN, W. Sobre a linguagem em geral e sobre a linguagem do homem. In:

BENJAMIN, W. Escritos sobre mito e linguagem (1915-1921). Tradução de Susana Kampff Lages e Ernani Chaves; organização, apresentação e notas de Jeanne Marie Gagnebin. São Paulo: Editora 34.

BENJAMIN, W. Passagens. Tradução do alemão de Irene Aron e do francês de Cleonice Paes Barreto Mourão. Belo Horizonte: UFMG; São Paulo: Imprensa Oficial, 2009.

BERDET, M. Walter Benjamin: la passion dialectique. Paris: Armand Colin, 2014. BIER, F. Para além da norma: violência mítica/violência divina em Walter Benjamin. Ideias, Campinas, n. 7, nova série, $2^{\circ}$ sem., 2013, p. 203-224.

BUTLER, J. Critique, coercion, and sacred life um Benjamin's 'Critique of violence'. In: VRIES, Hent de; SULLIVAN, Lawrence E (Org.). Political theologies: public religions in a post-secular world. New York: Fordham University Press, 2006.

CHAVES, E. Mito e política: notas sobre o conceito de destino no “jovem” Benjamin. Tran/Form/Ação, São Paulo, v. 17, p. 15-30, 1994. Disponível em: <http://dx.doi.org/10.1590/s0101-31731994000100002> Acesso em: 12 dez. 2016.

GAGNEBIN, J. M. Limiar, aura e rememoração: ensaios sobre Walter Benjamin. São Paulo: Editora 34, 2014.

GAGNEBIN, J. M. Apresentação. In: BENJAMN, Walter. Escritos sobre mito e linguagem (1915-1921). Tradução de Susana Kampff Lages e Ernani Chaves; organização, apresentação e notas de Jeanne Marie Gagnebin. São Paulo: Editora 34, 2011. 
HAMACHER, W. Aforismo, greve: a Crítica da violência de Benjamin. In: BENJAMIN, A; OSBORNE, P. (Org.). A filosofia de Walter Benjamin: destruição e experiência. Rio de Janeiro: Zahar, 1997.

HEGEL, G. W. F. Princípios da filosofia do direito. Tradução Orlando Vitorino. São Paulo: Martins Fontes, 1997.

HONNETH, A. Patologías de la razón: historia y actualidad de la teoria crítica. Tradución por Griselda Mársico. Madrid: Katz, 2009.

JAREK, M. A constelação vida: política e linguagem na juventude de Walter Benjamin. 2016. 185 f. Tese (Doutorado em Filosofia) - Programa de Pós-Graduação em Filosofia, Departamento de Filosofia, Pontifícia Universidade Católica do Rio de Janeiro. Rio de Janeiro, 2016.

LÖWY, M. Walter Benjamin: aviso de incêndio: uma leitura das teses "Sobre o conceito de história". Tradução de Wanda Nogueira Caldeira Brant, apresentação e notas de Jeanne Marie Gagnebin e Marcos Lutz Müller. São Paulo: Boitempo, 2005.

LÖWY, M.. L' anarchisme messianique de Walter Benjamin. Les Temps Modernes, 40 années, n. 447, out. 1983. p. 772-794.

LUXEMBURGO, R.; LOUREIRO, I. M. (Org.). Rosa Luxemburgo: textos escolhidos (1914-1919). v. 2. São Paulo: Unesp, 2011.

MARTEL, J. Divine violence: Walter Benjamin and eschatology of sovereignty. New York, Routledge, 2012.

MARX, K.; ENGELS, F. A ideologia alemã: crítica da mais recente filosofia alemã em seus representantes Feuerbach, B. Bauer e Stirner, e do socialismo alemão em seus diferentes profetas (1845-1846). Supervisão editorial Leandro Konder; tradução de Rubens Enderle, Nélio Schneider, Luciano Cavini Martorano. São Paulo: Boitempo, 2007.

MARX, K.; ENGELS, F. Crítica do programa de Gotha. Tradução Rubens Enderle. São Paulo: Boitempo, 2012.

MATOS, A. S. de M. C. Nomos Pantokrator? Apocalipse, exceção, violência. Revista Brasileira de Estudos Políticos, Belo Horizonte, v. 105, p. 277-342, 2012. Disponível em: <http://www.pos.direito.ufmg.br/rbep/index.php/rbep/article/view/P.00347191.2012v105p277/188>. Acesso em: 03 jun. 2017.

NASCIMENTO, E. M. Apontamentos acerca do estado de exceção em Walter Benjamin. Cadernos Walter Benjamin, n. 18, jan.-jun., 2017, p. 124-131. Disponível em: <http://www.gewebe.com.br/pdf/cad18/texto_09.pdf. >. Acesso em: 10 maio 2017.

PACHUKANIS, E. Teoria geral do direito e marxismo. Tradução de Paul Vaz de Almeida. São Paulo: Boitempo, 2017. 
SELIGMANN-SILVA, M. Walter Benjamin: o estado de exceção entre o político e o estético. Outra Travessia, Florianópolis, n. 5, 2005, p. 25-38. Disponível em: <https://periodicos.ufsc.br/index.php/Outra/article/download/12579/11746>. Acesso em: 20 jul. 2017.

SILVA JÚNIOR, J. V. B. Violência e direito no estado de exceção efetivo segundo Walter Benjamin. Cadernos Walter Benjamin, n. 18, jan.-jun., 2017, p. 55-76. Disponível em: <http://www.gewebe.com.br/pdf/cad18/texto_05.pdf.>. Acesso em: 10 maio 2017.

SOREL, G. Reflexões sobre a violência. Tradução de Paulo Neves. São Paulo: Martins Fontes, 1992.

VIEIRA, R. B. Walter Benjamin: o direito, a política e a ascensão e colapso da República de Weimar (1918-9/1933). 2016. 248 f. Tese. (Doutorado em Direito). Programa de PósGraduação em Direito da Pontifícia Universidade Católica do Rio de Janeiro. Rio de Janeiro, 2016.

ŽIŽEK, S. Violência: seis reflexões laterais. Tradução de Miguel Serras Pereira. São Paulo: Boitempo, 2014. 